\title{
Research of valuable substances extraction from alcohol distillery stillage
}

\author{
Oleksandr Ivashchuk ${ }^{1}$, Tetiana Kuzminchuk ${ }^{1}$, Roman Chyzhovych ${ }^{1}$, Semen Khomyak ${ }^{2}$, \\ Yevgen Semenyshyn ${ }^{1}$, Sofiia Kiiaieva ${ }^{1}$, Roman Zherebetskyi ${ }^{3}$ \\ 1. Department of Chemical Engineering, Lviv Polytechnic National University, UKRAINE, Lviv, 12 Bandery str., \\ E-mail: oleksandr.s.ivashchuk@1pnu.ua \\ 2. Department of Technology of Biologically Active Substances, Pharmacy and Biotechnology, \\ Lviv Polytechnic National University, UKRAINE, Lviv, 12 Bandery str. \\ 3. Department of Organic Products Technology, Lviv Polytechnic National University, \\ UKRAINE, Lviv, 12 Bandery str.
}

\begin{abstract}
The purpose of research was to study possibility of extraction of valuable components from waste of alcohol production - alcohol distillery stillage. The influence of raw material moisture on the extraction process was investigated. The study of the optical properties of the obtained extracts by infrared spectroscopy was carried out.
\end{abstract}

Keywords - alcohol distillery stillage, secondary raw materials, extraction, polar solvents, infrared spectroscopy.

\section{Introduction}

Recently scientists have begun to pay more and more attention to environmental problems solving, the rational use of natural resources of the regions, the development of secondary raw materials recycling. For Ukraine the problem of waste disposal and reusing is extremely relevant, as the country is a leader in Europe in the amount of waste per capita [1].

The alcohol industry, producing ethanol from food raw materials, has a problem of accumulation of waste from the production of alcohol - distillery stillage. Due to the high chemical and biochemical consumption of oxygen, suspended solids, specific color and odor, low $\mathrm{pH}$ value purification of such waste in the filtration fields or its discharge into environmental water is impossible [2].

According to various literature data, the dry matter content in alcohol distillery stillage from different raw materials is about $10 \%$. In terms of dry matter, it contains: protein $-13.9-37.25 \%$, fat $-3.7-10.7 \%$, fiber $-6.2-11.25 \%$, various substances and micronutrients: calcium $-0.13-0.24 \%$, phosphorus $-0.29-0.69 \%$, amino acids: lysine, methionine, cystine, tryptophan, nitrogen-free extractives, as well as vitamins (A, D, E, B vitamins, folic acid), biotin (H), carotenoids, etc. [3].

\section{Experimental}

The aim of the research was to study the possibility of obtaining valuable components from the corn distillery stillage by extraction in the system «solid - liquid». The extraction process was done in a Soxhlet apparatus according to the method described in [4].

As a solvent, a polar substance was chosen - methylene chloride, that has positively proven itself in previous studies $[4,5]$. Methylene chloride has a low boiling point at $39.6{ }^{\circ} \mathrm{C}$. It is stable in working conditions, does not mix with water and it is easily removed from a product with low energy consumption [5].

The research was conducted with two types of raw materials. The first type - alcohol distillery stillage after the centrifugation process, obtained on the production line of SE «Vuzlove distillery» (Vuzlove, Lviv region, Ukraine), with a humidity of $70.98 \%$. The second type is the same raw material, pre-dried by filtration drying, with a moisture content of $6.67 \%$.

A spectral study in the infrared region, for the obtained extracts, was performed on a spectrophotometer SPECORD M80 (Carl Zeiss Jena). 


\section{Results and discussion}

The results of experimental studies of the extraction process from the alcohol distillery stillage are shown in Table 1.

Table 1

Extracts' concentrations of the alcohol distillery stillage extraction with methylene chloride.

\begin{tabular}{|c|c|c|}
\hline \multirow{2}{*}{ Time, $\min$} & \multicolumn{2}{|c|}{ C, g/l } \\
\cline { 2 - 3 } & Dry & Wet \\
\hline 120 & 6,40 & 1,20 \\
\hline 240 & 7,20 & 0,99 \\
\hline 360 & 6,97 & 1,11 \\
\hline 480 & 6,95 & 1,44 \\
\hline Yield, \% & 6,06 & 1,22 \\
\hline
\end{tabular}

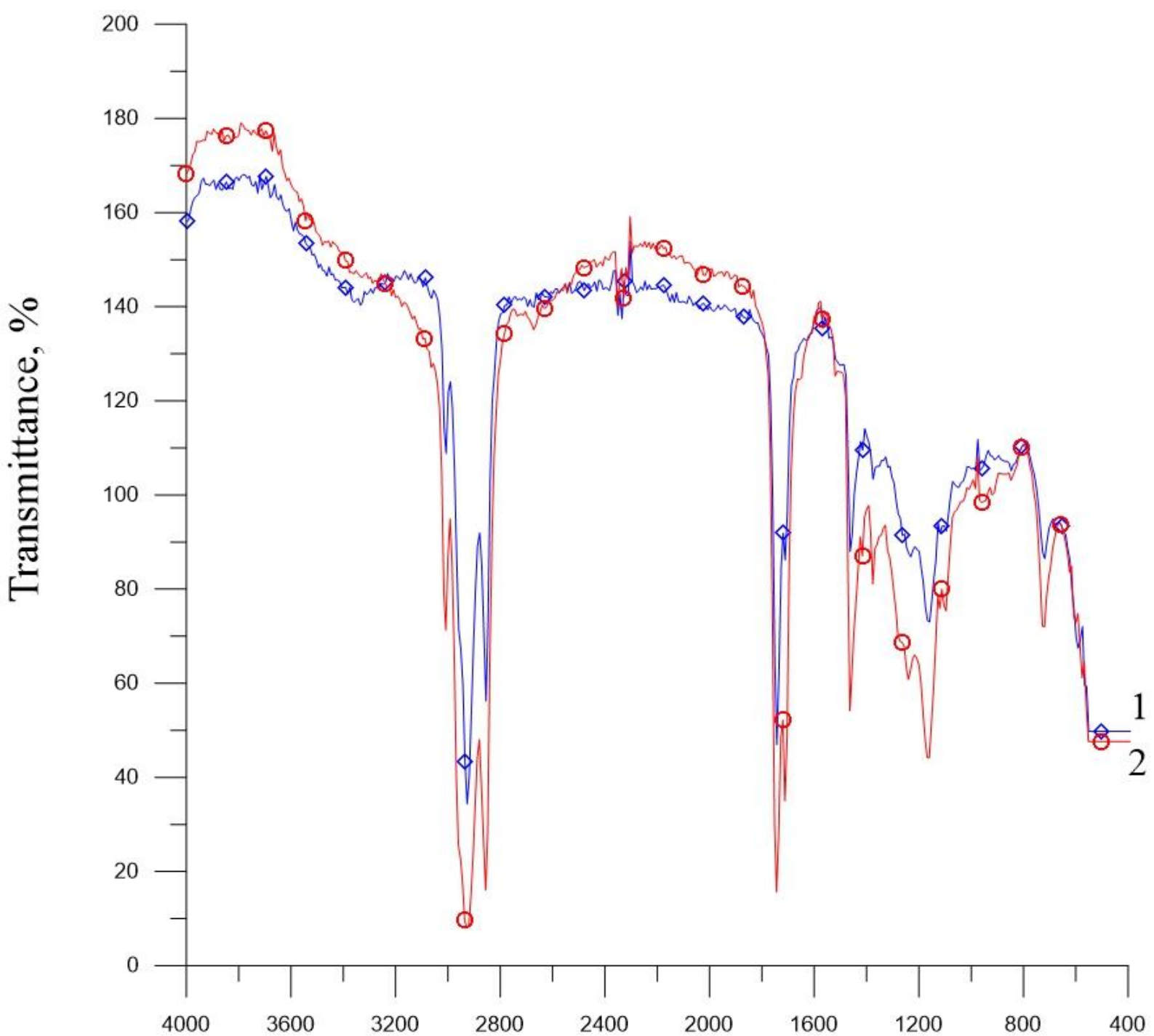

Wavenumber $(\lambda), \mathrm{cm}^{-1}$

Fig. 1. IR spectra of samples of distillery stillage extracts: 1 - pre-dried distillery stillage;

2 - distillery stillage obtained at the factory.s 
The results clearly show the positive effect of pre-drying the alcohol distillery stillage on the efficiency of the extraction process. However, such a reduction in the moisture content of the raw material requires more energy consumption for drying.

Infrared spectrophotometry of the obtained samples of extracts was also performed. The results are shown as the dependence of the transmission on the wavenumber (Fig. 1).

Analysis of the obtained data in the infrared region of the spectrum $\left(400-4000 \mathrm{~cm}^{-1}\right)$ showed the repetition of the main peaks in the spectra of both samples (Fig. 1). This indicates an insignificant effect of distillery stillage moisture on the quality of the product. The peaks on the IR spectrum are characteristic for substances found in vegetable oils [6]. This fact is expected because polar solvents are effective exactly for the extraction of vegetable oils [5, 6]. However, in the range of $3000-3300 \mathrm{~cm}^{-1}$ there is a difference, its explanation requires additional research.

\section{Conclusions}

Analysis of the results of studies of the distillery stillage extraction with different humidities shows that humidity is a factor that significantly affects the quantitative indicator of product yield. The use of pre-dried raw materials shows a positive effect on the concentration of the extract in the solvent. Due to the preliminary drying of the raw material from a humidity of $70.98 \%$ to $6.57 \%$, the product yield increased from $1.22 \%$ from wet material to $6.06 \%$ from dry one. However, on the other hand, spectral analysis indicates insignificant differences in the qualitative composition of the obtained extracts of distillery stillage with different humidities.

Thus, the extraction process allows the use of valuable components from the alcohol distillery stillage. Detailed identification of substances in the extracts requires additional research and analysis.

\section{References}

[1] Kryvenko, S.V. (2014). Suchasni pidxody do rozvytku recyklingu vtorynnykh materialnykh resursiv v konteksti «zelenoyi» industriyi. Naukovyj visnyk Poltavskogo universytetu ekonomiky i torgivli, 4(66), 83-89.

[2] Golub, N. B. (2018). Suchasni metody pererobky j utylizaciyi zernovoyi pislyaspyrtovoyi bardy. Innovative Biosystems and Bioengineering: international scientific e-journal, 2(2), 125-134.

[3] Hizhnjak, M.I. \& Cion', N.I. (2010). Spirtova barda jak cinna kormova dobavka j organichne dobrivo u sil's'komu gospodarstvi. Ribogospodars 'ka nauka Ukrajiny, 2, 122-130.

[4] Ivashchuk, O., Hlukhaniuk, A., Semenyshyn, Ye., Chyzhovych, R., Kuzminchuk, T. \& Khomyak, S. (2021). Influence of extraction conditions on qualitative composition of vegetable oils. Chemistry \& Chemical Technology, 15(2), 233-238.

[5] Hlukhaniuk, A.R., Kuzminchuk, T.A., Chyzhovych, R. A., Semenyshyn, Ye. M. \& Ivashchuk, O. S. (2020). Research of grinding degree influence and polar solvents nature on the efficiency of oil withdrawal from vegetable raw material using extraction method. Chemistry, Technology and Application of Substances, 3(1), 161-168.

[6] Chyzhovych R. A., Ivashchuk O. S., Khomyak S. V., Semenyshyn Ye. M., Kuzminchuk T. A., Anna Hlukhaniuk A. P., Zherebetskyi R., (2021). Research of rapeseed oil qualitative characteristics with IR spectroscopy. Monograph of the $9^{\text {th }}$ edition of the European Young Engineers Conference: Warsaw, Poland, 163. 